\title{
The behaviour of unsaturated compacted clay under plane strain condition
}

\author{
M. Fauziah ${ }^{1} \&$ H. R. Nikraz ${ }^{2}$ \\ ${ }^{1}$ Research student at Department of Civil Engineering, \\ Curtin University of Technology, Western Australia, \\ also lecturer at Indonesian Islamic University, Indonesia \\ ${ }^{2}$ Departement of Civil Engineering Curtin University of Technology, \\ Western Australia
}

\begin{abstract}
The behaviour of unsaturated soil is quite different from those of saturated soil because of the influence of suction. Although soils are generally assumed fully saturated below the groundwater table, they may be semi saturated near the state of full saturation under certain conditions. The situation of partial saturation may be caused by several factors, such as variation of water table level due to natural or manmade processes. This study was undertaken to delineate the effects of soil water suction on the behaviour of kaolin clay under plane strain condition, as more geotechnical problems in the field such as slope failure, earth retaining structures, and shallow foundation basically occur in plane strain conditions rather than tri axial condition. The biaxial apparatus, which was used in this study, is a modification of the conventional tri axial apparatus. Cell pressure from the tri axial compression test and a rigid loading platen are used to apply the minor $\left(\sigma_{3}\right)$ and major $\left(\sigma_{1}\right)$ principle stresses, respectively, to the clay specimen. The specimen is mounted inside the device, which fully restrains any out-of-plane deformation by the use of a pair of rigid perspex wall. The volume change of the sample was measured by local strain devices and laser sensor while the water volume change was recorded by a volume gauge. Results from the tests were compared with the theoretical analysis within the elasto-plastic critical state model for unsaturated soil.
\end{abstract}

Keywords: biaxial, partly saturated, matric suction, volume change. 


\section{Introduction}

An unsaturated soil is generally characterized by three phases, soil solids, water, and air. The presence of a fourth independent phase, a so called airwater interface or contractile skin was introduced by Fredlund and Morgenstern [7]. Based on multiphase continuum mechanics, a theoretical stress analysis of an unsaturated soil is presented by Fredlund and Morgenstern $[6,7]$. The analysis concluded that any two of three possible normal stress variables can be used to describe the stress state of an unsaturated soil. This is in contrast to saturated soil, where it is possible to relate the behaviour of the soil to the effective stress only. The presence of matric suction pressure is the main difference between saturated and unsaturated soil mechanics. It has been observed that several stability problems, involving soils used as construction materials, are due to water content changes and therefore to matric suction changes that occur periodically in nature.

The mechanical properties of soil usually are tested by the use of tri axial apparatus. However, field problems involving geotechnical structures are often plane strain situations and hence data obtained from tri axial testing would not apply. It would be more appropriate using data from plane strain compression testing. In addition to foundations, retaining walls and cuts in slope and other light structures are generally designed such that they are under unsaturated conditions as they remain above the water table. Mochizuki et al. [16] reported that when soil is tested under plane strain conditions, it, in general, exhibits a higher compressive strength and lower axial strain. Most of the plane strain apparatus used by previous researchers $[3,10,11,16,19]$, had the common feature of using rigid walls and tie-rods to impose a zero strain boundary condition in one of the principle axes. This method was found to be satisfactory, and friction between the rigid wall and test specimen could be adequately mitigated. Several researchers, $[1,13,18$, 27] found that if the aspect ratio (height to width) was bigger than 2 , the effect of loading platen friction and the restraint of loading frame would be negligible

The Behaviour of fined grained sands tested under plane conditions has been reported $[9,10,12,16,17]$ and the plane strain testing of clay has been initiated recently $[3-5,14]$. However published data of such tests especially for hard clay material and unsaturated soil are very limited. Lo et al. [15] presented a fracture model for soil and soft rock accordingly and thereby provided a rational basis for the prediction of such soil behaviour.

This study will present the behaviour of unsaturated clay specimens by the use of plane strain compression device, although the fracture characteristics of brittle clay may also be determined by this test apparatus. Details of the apparatus, specimen preparation and data evaluation are presented in the following discussion. Some results of the testing will be compared with the known soil mechanical concept. 


\section{Plane strain compression test}

\subsection{Description of the plane strain compression test}

A conventional triaxial apparatus was modified for the purpose of plane strain testing in this study. The plane strain arrangement is placed in a cell, with the height of $300 \mathrm{~mm}, 200 \mathrm{~mm}$ internal diameter and $30 \mathrm{~mm}$ wall thickness. A specimen of initial width of $36 \mathrm{~mm}$, height of $72 \mathrm{~mm}$, and thickness of $72 \mathrm{~mm}$, so that the aspect ratio is 2 , is placed on the base pedestal where it is restrained laterally by two rigid perspex plates to restrain its out-of plane movement. A high air-entry disc (HAED) was used as the interface between the unsaturated soil and the pore water pressure measuring system. This was to prevent any air from passing throught the disc into the measuring system, provided that the matric suction did not exceed the air-entry value of the disc. To offset the likelihood of scratching and reduced friction, all surfaces which are in contact with the specimen are lubricated. The cell is filled with water to enable the specimen to be pressurized laterally using the pressure generator for applying confining pressure. Figure 1 shows the plane strain arrangement.

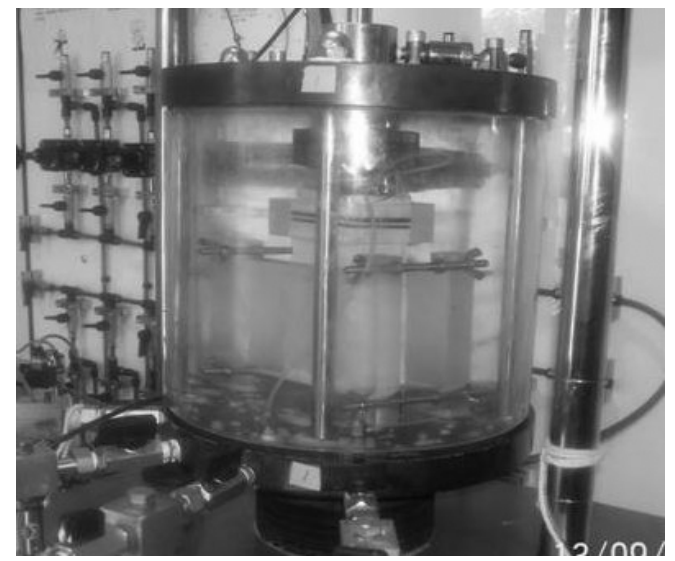

Figure 1: The plane strain arrangement.

To measure the axial load of the specimen, a $5 \mathrm{kN}$ capacity of submersible load cell was used. The axial displacements of the test specimen are measured by 35$\mathrm{mm}$ range LVDT (Linear Vertical Displacement Transducer) which was attached on top of the top cover of the cell. Four pore pressure transducers were used and mounted to the base plate of the cell to measure the applied cell pressure, back pressure pore pressure and flush pressure of the specimen. The global volume change of the water-saturated soil specimens are monitored by an automatic volume change unit which is connected to the back-pressure line. For the purpose of recording the displacement, loads, pressure and volume change reading a data acquisition system consisting of data logger and a set of microcomputer were used. Package software was used to convert digital bit data from the ADU (Analogue 
digital Unit) to engineering units based on the calibration of the relevant measuring unit, which was done before running the plane strain test.

\subsection{Specimen preparation}

The material used in this study was commercial Kaolin clay. The basic characteristics of the material are shown in Table 1.

Table 1: $\quad$ Characterization and classification test of the material.

\begin{tabular}{|l|c|}
\hline \multicolumn{1}{|c|}{ Type of test } & Value \\
\hline Liquid limit (ASTM D-4318) & $53.5 \%$ \\
\hline Plastic limit (ASTM D-427) & $30.76 \%$ \\
\hline Plasticity Index & $22.74 \%$ \\
\hline Specific Gravity (ASTM D-854) & 2.60 \\
\hline
\end{tabular}

Firstly, a kaolin clay sample was slurried to a uniform consistency of $1 \frac{1}{2}$ times its liquid limit, then consolidated in a steel cylindrical mould with the height of $600 \mathrm{~mm}$ and $150 \mathrm{~mm}$ in diameter at a maximum pressure of $300 \mathrm{kPa}$ in three stages. Two circular perspexes were placed at both ends of the slurry in the mould to apply the pressure evenly to the slurry. The slurry was allowed to consolidate by its own weight and small pressure was applied to prevent the slurry being squeezed out between the circular perspexes and the mould. A higher vertical pressure was applied when there was no further settlement change. The soil was extruded from the mould into lubricated formers when the consolidation process completed. Following this, the specimen and the former were wrapped in plastic film sheeting after sealing both their faces with liquid wax. To obtain even pore water pressure, the specimens were placed in the dehumidifier for at least 2 days until it was tested.

In the plane strain test set-up, the rubber membrane was firs placed over the test specimen with the aid of a sleeve stretcher. The rectangular porous plate was then placed on top of the specimen followed by the top assembly and the high air-entry disc (HAED). The rubber membrane was next slipped over the porous plate, the top assembly and the HAED and secured by the use of a set of O-rings and rectangular Perspex clamp. The specimen, together with the porous plate and the top assembly were then placed over the pedestal of the plane strain compression apparatus. The rubber membrane was next slipped over the pedestal and secured by the use of a set of O-rings and clamp set. Two rigid perspex plates were then placed and secured by the use of clamp set (Figure 2). The pressure cell, top assembly and laser sensor set-up were then installed.

\subsection{Test procedure and method}

Initially, the specimen was saturated until the B-value of the specimen reached the value of $0.95-0.98$. In order to provide an initial net normal stress of 


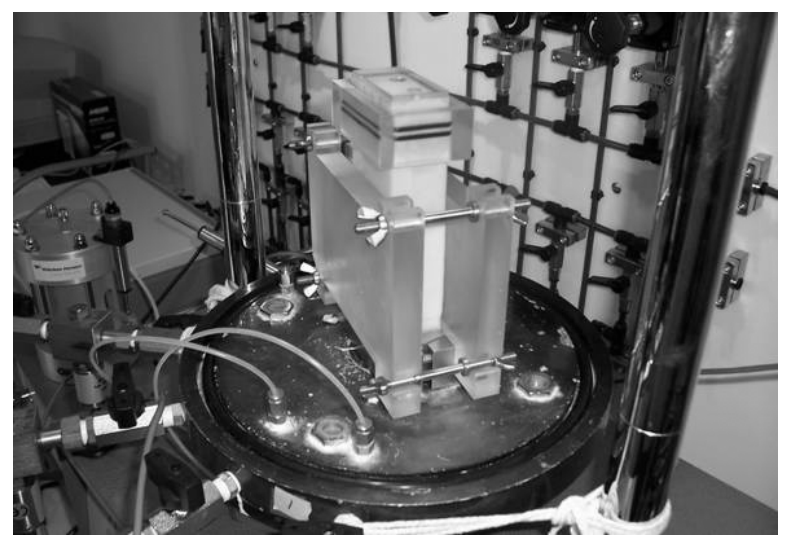

Figure 2: $\quad$ Part of the plane strain test set up.

$\left(\sigma_{3}-u_{a}\right)=0$ and matric suction of $\left(u_{a-} u_{w}\right)=10$, a cell pressure of $\sigma_{3}=600$ $\mathrm{kPa}$, back pressure of $u_{w}=590 \mathrm{kPa}$ and pore pressure of $u_{a}=600 \mathrm{kPa}$ were then applied to the specimen.The volume change of the soil skeleton $\Delta V S$ was monitored continuously by the laser sensors based on measurements taken at time intervals of 15 minutes. As the specimen properties and loading configuration were taken to be isotropic, the volumetric strain and hence change in volume of the soil skeleton $\Delta V S$ could be determined from the lateral strain. The change in volume of water in the specimen $\Delta V w$ was also monitored continuously by the volume change gauge which was connected to the backpressure line. Once the changes in the soil and water volumes had ceased, the test specimen was presumed to have fully consolidated under a matric suction of $10 \mathrm{kPa}$.

To flush out any air bubbles that might accumulate below the high air entry disc (HAED), the volume change gauge was set to by pass mode and the flushing line opened to a back-pressure of $50 \mathrm{kPa}$. Once the flushing was complete, the flushing line was closed and the volume change gauge set to flow mode. The matric suction $\left(u_{a}-u_{w}\right)$ was next increased to $20 \mathrm{kPa}$ by reducing the back pressure to $u_{w}=580 \mathrm{kPa}$. The corresponding changes in the soil skeleton and water volumes, $\Delta V S$ and $\Delta V w$ were monitored continuously until they had ceased, at which stage the corresponding void ratio $e$ and the water content $w$ of the test specimen were computed from the cumulative changes in soil skeleton and water volumes. Air bubbles accumulating below the HAED were then flushed out as before. Thereafter, the entire procedure, that is from increasing the matric suction to the desired value up to flushing out the air bubbles, was repeated for matric suctions $\left(u_{a}-u_{w}\right)$ of $50,100,200,300$, and $500 \mathrm{kPa}$ respectively, which were applied by reducing the back pressure accordingly.

The specimen was then sheared by elevating the base of the confining pressure cell at a constant velocity of $0.08 \mathrm{~mm} / \mathrm{m}$ with the drainage line closed. 
This loading rate was deduced based on the permeability of adopted kaolin clay suggested by Bishop and Henkel [2]. During shearing the suction in the specimen was maintained at a constant matric suction of $500 \mathrm{kPa}$. The data were recorded at 3 minute interval test and it was terminated at the axial strain of about $20 \%$ or sooner. Following this, the specimen was taken out immediately for the purpose of moisture content test.

In the analysis of the behaviour of the brittle unsaturated clay, the pore pressure parameter would be required in order to the determined the pore pressure increments and the matric suction. The pore pressure parameters were deduced from the volumetric deformation coefficient, which was obtained by laboratory testing. This procedure was proposed by Fredlund and Rahardjo [8], although adapted to plane strain conditions.

\section{Test result and discussion}

The typical result given by three drained test $\mathrm{NC}, \mathrm{PC}$, and $\mathrm{NR}$ will be present in the following discussion. The specimen in test $\mathrm{PC}$ had pre crack of length $3 \mathrm{~mm}$ $\mathrm{cm}$, the specimen in test NC was "intac", and the specimen in test NR was "intact" specimen under tri axial test set up. The soil states of remoulded kaolin clay specimen are summarized in Table 2.

Table 2: $\quad$ Value of state parameters of the specimen.

\begin{tabular}{|l|l|c|c|c|c|c|}
\hline \multirow{2}{*}{$\begin{array}{l}\text { Test } \\
\text { Name }\end{array}$} & \multicolumn{3}{|c|}{ Initial condition } & \multicolumn{3}{c|}{ After shearing } \\
\cline { 2 - 7 } & $w(\%)$ & $E$ & $S r$ & $w(\%)$ & $e$ & $S r$ \\
\hline NC & 24.43 & 0.688 & 92.323 & 17.72 & 0.613 & 75.158 \\
\hline PC & 24.47 & 0.730 & 87.153 & 18.01 & 0.693 & 67.570 \\
\hline NR & 23.36 & 0.719 & 84.473 & 17.13 & 0.692 & 64.361 \\
\hline
\end{tabular}

Note : w, water content; $e$, void ratio; Sr, Degree of saturation.

Figure 3 shows the relationship between shear stress and vertical strain at the same matric suction of $500 \mathrm{kPa}$. The shear stress increase monotonically with the increasing vertical strain up to the peak stress of $124.519 \mathrm{kPa}, 175.926 \mathrm{kPa}$ and $228.395 \mathrm{kPa}$ at about about $3.33 \%, 3.64 \%$ and $3.87 \%$ axial strain for $\mathrm{PC}, \mathrm{NC}$, and NR, respectively, then followed by strain softening behaviour to critical state. The results are fairly typical for specimen of brittle, hard partly saturated soil specimen and exhibit elastic-only fracture. This is in accordance with the model proposed by Lo et al. [15]. The "intact" specimen of test NC showed a higher peak strength than that the fissured specimen of test PC. The presence of a fissure or discontinuity makes the soil weaker as the effective area offering resistance to shear is reduced. The shear strength along a surface of discontinuity is thereby less than that of the intact material. Compared to the "intact" specimen 


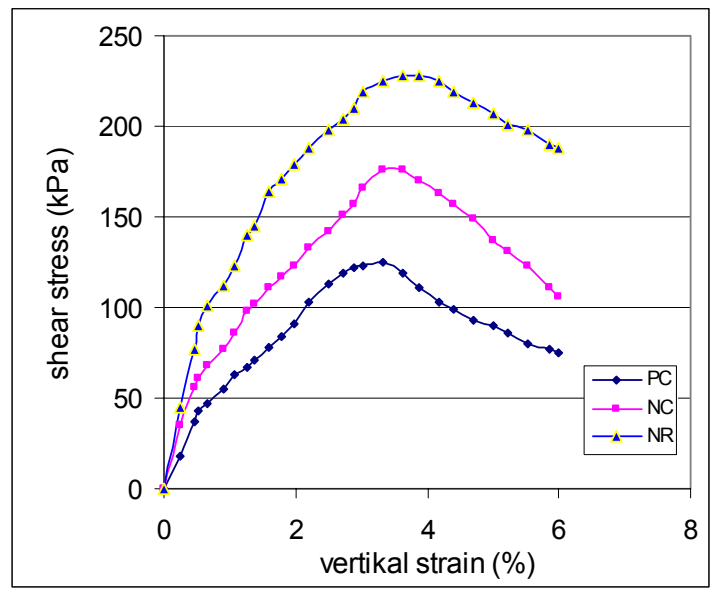

Figure 3: Stress-strain behaviour of the specimen.

testing without rigid wall of test NR, not only had higher peak stress, the specimen of test NC also had higher shear strength along the vertical strain. This is in well agreement with the founding of Mochizuki et al. [16].

Figure 4 presents the influence of matric suction on volume change of the specimen. In general it is clearly shown that for all specimens, the volumetric strain was rising with the increasing of the matric suction. The compressive volumetric strains are taken as positive. The tendency in plane strain test seems to be compressive volume change. Similar to the stress-strain of specimen test on Figure 3, because of the presence of the crack or discontinuities on the PC specimen, it makes the specimen weaker than that the "intact" specimen of NC.

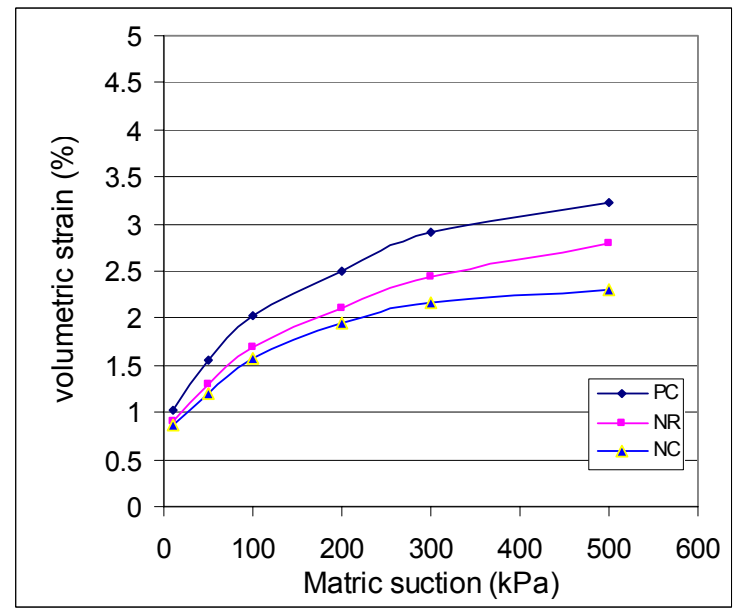

Figure 4: Influence of matric suction on volumetric strain of the specimen. 
The specimen of PC had the lowest compressive strength than that the other specimen. Compared to the specimen under the tri axial of test NR, the bi axial specimen of test NC had higher shear strength along the vertical strain. This is in consistent with the founding of Mochizuki et al. [16].

\section{Conclusions}

The following conclusions may be drawn from this experimental study.

(1) The apparatus have been able to provide the test result that in accordance with known soil behaviour.

(2) The shear test result showed that the specimen tested is typical for specimen of brittle, hard partly saturated soil specimen and exhibit elastic-only fracture.

(3) The discontinuities of the specimen affected to the shear strength and the compressive strength of the specimen.

\section{Acknowledgements}

We would like to thank all those involved in the project, especially to Associate Professor Kwang Wei Lo and Dr. Min Min Zhao for valuable advice and Mr. Pontjo Utomo and Mr. Paisar Syakur, both research students at Curtin University of Technology, for their assistance, commitment and care.

\section{References}

[1] Bishop, A.W. and Green, G.E., The influence of end restraint on the compression strength of cohessionless soil, Geotechnique, 15 (3), pp. 243 266, 1965.

[2] Bishop, A.W. and Henkel, D.J., The measurement of soil properties in the triaxial test, $2^{\text {nd }}$ Ed., Arnold, London, 1962.

[3] Drescher, A., Vardoulakis, I. and Han, C., A Biaxial apparatus for testing soils, Geotechnical Testing Journal, GTJODJ, 13, pp. 226-234, 1990.

[4] Fauziah, M. and Nikraz, H., Biaxial testing of overconsolidated clay, Proceeding of The $1^{\text {st }}$ International Conference of European Asian Civil Engineering Forum, Jakarta, Indonesia, 2007.

[5] Fauziah, M. and Nikraz, H., Stress-strain behaviour of overconsolidated clay under plane strain condition, Proceeding of $10^{\text {th }}$ Australia New Zealand conference on geomechanics, pp. 148-153, Brisbane, Australia, 2007.

[6] Fredlund, D.G. and Morgenstern, N.R., Constitutive relation for volume change in unsaturated soil, Canadian Geotechnique Journal, 13 (3), pp. 261-276, 1976.

[7] Fredlund, D.G. and Morgenstern, N.R., Stress state variables for unsaturated soils, Journal of Geotechnical Engineering ASCE, 103 (5), pp. 447-466, 1977. 
[8] Fredlund, D.G. and Rahardjo, H., Soil mechanics for unsaturated soil, John Wiley \& Sons, Inc, 1993.

[9] Han, C. and Drescher, A., Shear bands in biaxial tests on dry coarse sand, Soils and Foundations, Japanese Society of Soil Mechanics and Foundation Engineering, 33 (1), pp. 118-132, 1993.

[10] Han, C and Vardoulakis, I.G., Plane strain compression experiments on water-saturated fine-grained sand, Geotechnique, 41(1), pp. 49-78, 1991.

[11] Green, G.E. and Reades, D.W., Boundary conditions, anisotropy and sample shape effects on the stress-strain behaviour of sand in triaxial compression and plain strain, Geotechnique, Vol.25, No.2, pp. 333-356, 1975.

[12] Lee, K.L., Comparison of plane strain and triaxial tests of sand, Journal of the Soil Mechanics and Foundation Division. ASCE, 96(3), 1970.

[13] Lee, K.L. and Seed, H.B., Discussion on use of free end in triaxial testing on clays, ASCE, 91 (6), pp. 173-177, 1964.

[14] Lo, K.W., Mita, K.A. and Tamiselvan, T., Plane strain testing of overconsolidated clay, Research Report, Department of Civil Engineering, National University of Singapore, 2000.

[15] Lo, K.W., Nikraz, R.H., Tamiselvan, T. and Zhao, M.M., An elastoplastic shear fracture model for soil and soft rock, Proc of the 11th International Conference on Fracture, Turin, Italy, 2005, www.icf11.com/proceeding/TOPIC/topic.htm

[16] Mochizuki, A., Min, C. and Takahashi, S.A., A method for plane strain testing of sand, Journal of Japanese Geotechnical Society, 475, pp. 99-107, 1993.

[17] Marach, N.D., Duncan, J.M., Chan, C.K. and Seed, H.B., Plane strain testing of sand, laboratory shear strength of soil, ASTM STP 740, pp. 294 302, 1981.

[18] Rowe, P.W. and Barden, L., Importance of free ends in triaxial testing, ASCE, 90 (1), pp.1-27, 1964.

[19] Viggiani, G., Finno, R.J. and Harris, W.W., Experimental observations of strain localisation in plane strain compression of a stiff clay, In Localisation and Bifurcation Theory for Soils and Rocks, Chambon et al., Eds., Balkema, Rotterdam, pp. 189-198, 1994.

[20] Taylor, D.W., $7^{\text {th }}$ Progress report on shear strength to US Engineers, Massachusetts Institute of Technology, 1941. 